\title{
Transformed Hairy Roots of Discaria trinervis: A Valuable Tool for Studying Actinorhizal Symbiosis in the Context of Intercellular Infection
}

\author{
Leandro Imanishi, ${ }^{1}$ Alice Vayssières, ${ }^{2}$ Claudine Franche, ${ }^{2}$ Didier Bogusz, ${ }^{2}$ Luis Wall, ${ }^{1}$ and \\ Sergio Svistoonoff ${ }^{2}$ \\ ${ }^{1}$ Laboratorio de Bioquímica, Microbiología e Interacciones Biológicas en el Suelo (LBMIBS), Departamento de Ciencia y \\ Tecnología, Universidad Nacional de Quilmes, R. Sáenz Peña 352, B1876BXD Bernal, Argentina; ${ }^{2}$ Groupe Rhizogenèse, \\ Unité Mixte de Recherche Diversité Adaptation Développement des Plantes (DIADE), Institut de Recherche pour le \\ Développement (IRD), 911 avenue Agropolis, BP 64501, 34394 Montpellier Cedex 5, France
}

Submitted 29 March 2011. Accepted 2 May 2011.

\begin{abstract}
Among infection mechanisms leading to root nodule symbiosis, the intercellular infection pathway is probably the most ancestral but also one of the least characterized. Intercellular infection has been described in Discaria trinervis, an actinorhizal plant belonging to the Rosales order. To decipher the molecular mechanisms underlying intercellular infection with Frankia bacteria, we set up an efficient genetic transformation protocol for $D$. trinervis based on Agrobacterium rhizogenes. We showed that composite plants with transgenic roots expressing green fluorescent protein can be specifically and efficiently nodulated by Frankia strain BCU110501. Nitrogen fixation rates and feedback inhibition of nodule formation by nitrogen were similar in control and composite plants. In order to challenge the transformation system, the MtEnod11 promoter, a gene from Medicago truncatula widely used as a marker for early infection-related symbiotic events in model legumes, was introduced in D. trinervis. MtEnod11::GUS expression was related to infection zones in root cortex and in the parenchyma of the developing nodule. The ability to study intercellular infection with molecular tools opens new avenues for understanding the evolution of the infection process in nitrogen-fixing root nodule symbioses.
\end{abstract}

The availability of nitrogen is a limiting factor for plant growth in many ecosystems. Among adaptations that enable plants to cope with nitrogen deficiency are symbiotic associations with soil bacteria able to produce ammonium from atmospheric nitrogen. A key evolutionary invention was the development of specialized structures (root nodules) in which bacteria are hosted intracellularly, dramatically increasing the efficiency of nutrient transfers. However, the capacity to enter root nodule symbiosis (RNS) is limited to two groups of plants, legumes and Parasponia spp. (Celtidaceae), that interact with a group of gram-negative proteobacteria collectively called rhizobia; and actinorhizal plants, a group of 220 species distributed in the orders Fagales, Cucurbitales, and Rosales, that interact with gram-positive Actinobacteria of the genus Frankia (Vessey

L. Imanishi and A. Vayssières contributed equally to this work.

Corresponding author: L. Wall; E-mail: lgwall@unq.edu.ar et al. 2005). Strikingly, all these plants belong to the Rosid I clade, suggesting a common origin for the ability to establish RNS (Soltis et al. 1995; Sprent 2007).

The great amount of research performed on model legumes in recent decades led to the discovery of key molecular steps giving rise to nodule formation. A major breakthrough was the identification of Nod factors, lipochito-oligosaccharides synthesized by rhizobia that enable their specific recognition (Lerouge et al. 1990), followed by the deciphering of the corresponding signaling pathway (Kouchi et al. 2010). Much less is known about non-model legumes and actinorhizal plants but recent reports suggest that at least some of the genetic mechanisms enabling model legumes to recognize their symbionts are also used by non-model legumes (Capoen et al. 2005, 2009), actinorhizal plants (Markmann et al. 2008; Gherbi et al. 2008a) and Parasponia spp. (Op den Camp et al. 2011), supporting the hypothesis that all plants that are able to enter RNS share genetic features allowing nodulation. At least some of these features have evolved from the more ancient and widespread symbiosis involving arbuscular mycorrhizal fungi (Maillet et al. 2011; Op den Camp et al. 2011).

The genetic developmental program leading to nodulation implies coordination between cell infection and organ development. This program has recently been finely dissected by analyzing a collection of Lotus japonicus spontaneously nodulating mutants. The authors concluded that intercellular root invasion and single-cell infection without the formation of any kind of transcellular infection threads is the most ancestral process that might have evolved into the crack entry and, more recently, into the intracellular root hair infection mechanisms observed in most legumes (Madsen et al. 2010).

Although root hair infection by symbiotic bacteria has been extensively studied at the molecular level in model legumes (Gage 2004; Sprent 2007) and also in different actinorhizal symbioses (Svistoonoff et al. 2010a; Wall and Berry 2008), much less is known about the other modes of infection, including crack entry and intercellular infection, that take place in approximately $35 \%$ of legume genera and $75 \%$ of actinorhizal genera (Sprent 2007; Wall 2000). This is partly because most of these plants are tropical trees or shrubs in which few genetic tools are available. The establishment of a genetic transformation protocol based on the generation of composite plants using Agrobacterium rhizogenes has greatly facilitated the functional 
analysis of symbiotic genes (Stougaard et al. 1987). Composite plants have been widely used to characterize symbiotic genes in model legumes (Boisson-Dernier et al. 2001; Díaz et al. 2005; Díaz et al. 1989; Petit et al. 1987) and, more recently, to explore the conservation of symbiotic mechanisms in non-model plants such as Sesbania rostrata (Capoen et al. 2005), Arachis hypogea (Sinharoy et al. 2009), Aeschynomene spp. (Bonaldi et al. 2010), Casuarina glauca (Diouf et al. 1995; Gherbi et al. 2008a), Datisca glomerata (Markmann et al. 2008), and P. andersonii (Op den Camp et al. 2011). However, in legume or actinorhizal plant species, no system of transformed hairy roots has been reported to form nitrogen-fixing nodules via intercellular invasion and single-cell infection as the main bacterial infection pathway of the root.

Discaria trinervis appeared to be a good candidate to develop such a tool: $D$. trinervis belongs to the family Rhamnaceae in the order Rosales, for which very little molecular information is available; a pure Frankia strain BCU110501 isolated from D. trinervis field nodules is available (Chaia 1998), and its genome is currently being sequenced (D. Benson, L. Tisa, and L. Wall unpublished results). D. trinervis infection by Frankia bacteria was analyzed in detail in a time course experiment and described as intercellular (Valverde and Wall 1999a). It is worth noting that no infection thread was detected at any stage in the infection and nodule development process (Valverde and Wall 1999a). D. trinervis also appears to be specifically nodulated by Frankia bacteria belonging to cluster 3. Strains belonging to this cluster are also infective in Elaeagnaceae genera and other Rhamnaceae plants (Benson and Dawson 2007; Wall 2000); the regulation of its nodulation, modulated by $\mathrm{N}$ and $\mathrm{P}$, has been described (Valverde and Wall 1999b, 2002; Valverde et al. 2000; Wall et al. 2003); and diffusible factors from Frankia BCU110501 have been shown to modulate infection and nodulation in D. trinervis (Gabbarini and Wall 2008).

Here, we describe the set-up used for the genetic transformation of the $D$. trinervis root system based on A. rhizogenes. We compare the classic in vitro transformation system (Diouf et al. 1995) with the easier ex vitro one (Collier et al. 2005). We show that co-transformed roots can be specifically and efficiently nodulated with Frankia BCU110501, the resulting nodules being undistinguishable from nontransgenic nodules in terms of developmental timing, anatomy, nitrogen fixation, and feedback control by nitrogen. We also show that the expression of reporter genes such as $\beta$-glucuronidase $(G U S)$ and green fluorescent protein $(G F P)$ can be easily detected within transgenic $D$. trinervis root systems. In an application of this technique, we demonstrate that the promoter of MtEnod11, a nodulin gene from Medicago truncatula, widely used as a marker for early infection-related symbiotic events in model

Table 1. Efficiency of in vitro transformation of Discaria trinervis seedlings with Agrobacterium rhizogenes strains ARqua1 or A4RS

\begin{tabular}{lcc}
\hline & \multicolumn{2}{c}{ Percent efficiency per A. rhizogenes strain } \\
\cline { 2 - 3 } Inoculation method & A4RS & ARqua1 \\
\hline Cut & $7.5(n=40)$ & $8.6(n=35)$ \\
Stab & $28.6(n=35)$ & $22.5(n=40)$ \\
\hline
\end{tabular}

legumes (Boisson-Dernier et al. 2001), retains its symbiotic activation in transgenic $D$. trinervis nodules.

\section{RESULTS}

\section{Transformation set-up.}

On the basis of previous experiments performed with the actinorhizal plant $C$. glauca, we analyzed the susceptibility of $D$. trinervis to two strains of $A$. rhizogenes, A4RS, an agropinetype strain often used due to its ability to induce hairy-roots induction (Petit et al. 1983) and the low-virulence strain ARqua1 (Quandt et al. 1993). Both strains contained a pHKN29 plasmid with a $35 S:: G F P$ fusion (Kumagai and Kouchi 2003). The hypocotyls of aseptically grown seedlings of $D$. trinervis were inoculated using a needle as described for stab inoculation of C. glauca (Diouf et al. 1995) or by sectioning the radicle with a knife dipped in an $A$. rhizogenes culture as usually performed for $M$. truncatula knife-cut inoculation (Boisson-Dernier et al. 2001). One week after inoculation, the first calli expressing GFP appeared at the inoculation site. Ten days after inoculation, strongly fluorescent roots began to emerge from these calli (Fig. 1A to C). Screening of co-transformed roots based on GFP fluorescence yielded a co-transformation efficiency ranging from 7.5 to $28.6 \%$ (Table 1). The stab method resulted in higher co-transformation efficiencies than the knife method. Both strains yielded similar results; however, when plants were transferred to hydroponics and allowed to develop, marked differences between the two strains became apparent. Genetic transformation had a significant impact on root system architecture: root systems of transgenic plants were shallower and more branched than nontransgenic controls, and this phenotype was more apparent in plants inoculated with A4RS (Fig. 1D). We concluded that stab inoculation with ARqual was the best compromise to obtain good co-transformation efficiency while minimizing the impact on root system architecture. This method was used thereafter.

In an attempt to improve this protocol, we tested whether the addition of acetosyringone, a molecule known to activate Agrobacterium spp.-mediated T-DNA transfer, had any effect on co-transformation efficiency. Seedlings were transformed as described above and acetosyringone was added after inoculation with $A$. rhizogenes ARqual at concentrations ranging from 10 to $100 \mu \mathrm{M}$. However, no differences were detected in co-transformation efficiency compared with plants transformed without acetosyringone (data not shown).

Given the limited results obtained with the in vitro transformation method, we tried to produce composite plants using an ex vitro method reported to be successful in several plant species (Collier et al. 2005). Following the original method (Collier et al. 2005), two conditions were tested. Plants were either continuously watered with demineralized water, or subjected to water stress for $48 \mathrm{~h}$ and subsequently continuously watered with demineralized water. Transgenic roots appeared between the third and fifth week after inoculation with ARqua1. The co-transformation efficiency reached $80 \%$ without water stress and $68 \%$ with water stress (Table 2). Although the water stress step appeared to enhance co-transformation efficiency in terms of the numbers of transformed roots per plant and the percent-

Table 2. Efficiency of ex vitro transformation of Discaria trinervis

\begin{tabular}{|c|c|c|c|c|c|c|}
\hline \multirow[b]{2}{*}{ Stress } & \multirow[b]{2}{*}{ Co-transformation $(\%)^{b}$} & \multicolumn{2}{|c|}{ GFP roots/plant ${ }^{\mathrm{a}}$} & \multicolumn{2}{|c|}{ Inoculation method $^{\mathrm{a}}$} & \multirow[b]{2}{*}{ Stab/cut ratio } \\
\hline & & Average number & Percent & Stab & Cut & \\
\hline Water stress & $68.09(n=47)$ & $3.00(1-8)$ & $39.01+24.12(8.33-100)$ & $1.72+1.33(0-5)$ & $1.28+1.57(0-5)$ & 1.34 \\
\hline No stress & $80.49(n=41)$ & $2.45(1-7)$ & $31.93+18.22(5.88-70)$ & $1.76+1.41(0-6)$ & $0.67+1.00(0-4)$ & 2.63 \\
\hline
\end{tabular}

average results + standard deviation; range values are in parentheses.

${ }^{\mathrm{b}}$ Co-transformation efficiency: percentage of plants with at least one root expressing green fluorescent protein (GFP). 
age of transformed roots per cutting, it did not yield more explants with at least one co-transformed root. Overall, the best method to obtain composite plants was stab inoculation performed ex vitro using the ARqual strain without any water stress. This method was used hereafter.

\section{Infection, nodule development, and nodule function in transformed roots.}

Because previous studies on legumes and the actinorhizal tree C. glauca reported that nodulation can be altered in composite plants (Beach and Gresshoff 1988; Diouf et al. 1995), we investigated whether the transformation protocol had an impact on nodule development, morphology, and function. Composite plants transformed with ARqual containing the GFP reporter gene under the control of the $35 \mathrm{~S}$ promoter, and nontransgenic control plants, were grown in hydroponics and inoculated with Frankia BCU110501. Composite plants under the UV stereomicroscope were checked periodically and any nonfluorescent roots were removed. All inoculated plants developed anatomically normal nodules that could be detected with the naked eye as root bumps appearing approximately 1 week after inoculation. Nodules were of indeterminate type with several lobes (Fig. 1E and F). Sections of these nodules revealed the three zones characteristic of actinorhizal nodules: the meristematic zone near the apex; the infection zone, in which cortical cells start to be infected by Frankia bacteria; and the fixation zone, in which infected cells become hypertrophied and are full of Frankia filaments. Infected cells in the fixation zone were larger and contained numerous vesicles (Fig. $1 \mathrm{G}$ and $\mathrm{H}$ ), a sure sign of nitrogen fixation. These anatomical features are similar to those previously described for $D$. trinervis grown in pouches (Valverde and Wall 1999a). No differences in anatomy or in the time needed to reach a given developmental stage were detected between transgenic and nontransgenic plants.

\section{Nitrogen regulation of nodulation functions normally.}

Nitrogen is a key regulator of nodulation of D. trinervis: the presence of nitrogen as either ammonia or nitrate strongly inhibits the formation of new nodules and nitrogen fixation in existing nodules (Streeter and Wong 1988). To analyze whether this regulation is maintained in transgenic roots, composite and control plants were inoculated with Frankia bacteria, and nitrogen in the form of $\mathrm{NH}_{4} \mathrm{NO}_{3}$ at a concentration of $100 \mathrm{ppm}$ was added to the nutrient solution 1 week before or after inoculation. The number of nodules and acetylene reduction activity (ARA) were scored 8 weeks after inoculation (Table 3). Nodules appeared 1 week after inoculation only in plants watered without $\mathrm{N}$ before inoculation. When $\mathrm{N}$ was added to the nutrient solution 1 week after inoculation, root bumps and nodule primordia never developed into mature nodules. Subsequently, as the roots grew older, these structures were almost not observed. ARA measurements showed similar values for transgenic and nontransgenic nodules when no $\mathrm{N}$ was added to the nutrient solution, reduced activity when $\mathrm{N}$ was added 1 week before ARA measurement, and no activity when $\mathrm{N}$ was added 1 week after inoculation (Table 3). Therefore, the negative regulation driven by nitrogen also functions normally in transgenic roots.

Frankia bacteria recognition specificity of transgenic roots.

To analyze whether genetic transformation had an impact on Frankia bacteria recognition specificity, nodulation tests were performed with BCU110501, the strain infective on D. trinervis (Chaia 1998), and two other strains, ACN14a and CcI3, infective on Alnus spp. and Casuarina spp., respectively, but not on Rhamnaceae plants such as Discaria spp. or Elaeagnaceae plants (Normand et al. 2007). Nodules appeared only in plants inoculated with BCU110501, again suggesting that transgenic roots behave in a way similar to that of nontransgenic roots with respect to symbiotic specificity.

\section{Composite $D$. trinervis plants: a tool for studying gene expression.}

Genetic transformation is very often used to study the regulation of gene expression using promoter::GUS fusions. To assess whether this approach is feasible on $D$. trinervis, we generated transgenic roots expressing a ProMtEnod11::GUS fusion. MtEnod11 is a gene from M. truncatula widely used as an early infection-related molecular marker for endosymbiotic associations involving both rhizobia and arbuscular mycorrhizal fungi (Boisson-Dernier et al. 2005). We recently reported that ProMtEnod11 is strongly activated in C. glauca nodules, particularly in the infection zone (Svistoonoff et al. 2010b). Composite plants were obtained and GUS activity was monitored before and after inoculation with Frankia BCU110501. No GUS activity was detected in nontransgenic control plants either before or after inoculation with Frankia bacteria (data not shown). Plants transformed with the ProMtEnod11::GUS construct showed GUS expression in the vascular system and in the apex of roots similar to that described in M. truncatula, C. glauca, and Allocasuarina verticillata (Boisson-Dernier et al. 2001; Journet et al. 2001; Svistoonoff et al. 2010b) (data not shown). This nonsymbiotic expression was used to screen the co-transformed root systems because, in contrast to pHKN29, GFP is not present in the pFP100 plasmid containing the ProMtEnod11::GUS construct. In mature nodules, strong GUS activity was detected at the apex, in meristematic cells, in differentiating cells in cortical and vascular tissues (Fig. 2A, B, D, and E), and in older vascular tissues (Fig. 2A and D). Activation of ProMtEnod11 in relation to Frankia infection was detected in the infection zone in cells infected by Frankia bacteria that do not yet fix nitrogen (Fig. 2C, E through G). As cells differentiated and Frankia bacteria started to develop vesicles, levels of GUS activity decreased (Fig. 2F and G) and almost no GUS staining was detectable in fully differentiated cells in the fixation zone (Fig. 2I). In young nodule primordia, strong GUS activity was observed in the meristematic zone and also in root cortical cells adjacent to the nodule primordia (Fig. $2 \mathrm{H}$ and I). Taken together, our results sug-

Table 3. Regulation of nodulation and nitrogenase activity by $\mathrm{N}$ in transformed roots of Discaria trinervis ${ }^{\mathrm{a}}$

\begin{tabular}{lcccc}
\hline Explants & Frankia bacteria & Nitrogen $(\mathbf{p p m})^{\mathbf{b}}$ & Nodules/plant & ARA nmol C $_{\mathbf{2}} \mathbf{H}_{\mathbf{4}} / \mathbf{h}$ plant \\
\hline Nontransgenic control & + & 0 & $7.00+3.00(4-10)$ & $363-519$ \\
GFP roots & - & 0 & 0 & 0 \\
GFP roots & + & 0 & $11.67+7.02(5-19)$ & $166-691$ \\
GFP roots & + & $100^{\mathrm{c}}$ & $9.67+3.06(7-13)$ & $0-144$ \\
GFP roots & + & $100^{\mathrm{d}}$ & 0 & 0 \\
\hline
\end{tabular}

\footnotetext{
${ }^{\mathrm{a}} \mathrm{ARA}=$ acetylene reduction activity and GFP $=$ green fluorescent protein. Range data values are in parentheses; $n=5$ plants per treatment

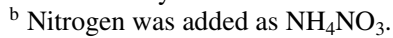

${ }^{\mathrm{c}}$ Nitrogen was added to fully nodulated plants 1 week before measurement of ARA.

${ }^{\mathrm{d}}$ Nitrogen was added 1 week after inoculation before nodule development but after infection.
} 
gest that ProMtEnod11 is activated in roots and nodules in the vascular bundle and meristematic tissues, and also in cortical cells infected by Frankia bacteria but not yet engaged in nitrogen fixation. This expression pattern is very similar to that reported during intracellular infection of $C$. glauca by Frankia bacteria (Svistoonoff et al. 2010b).

\section{DISCUSSION}

The recent dissection of the signaling network leading to nodulation performed with mutants of the model legume $L$. japonicus strongly suggests that intercellular root invasion and cell infection from the intercellular space, without the formation of infection threads, are evolutionary ancestral mechanisms allowing the accommodation of bacterial endosymbionts inside plant cells (Madsen et al. 2010). It is worth noting that all model plants that form RNS, either legumes or actinorhizal plants, develop infection threads at some stage of the infection process. D. trinervis appears to be an example of the most ancestral infection pathway and, in that respect, the development of the hairy root transformation protocol for this species is a valuable tool to study the genetic program operating in this type of plant-microbe interaction.
Co-transformation efficiencies using either A4RS or ARqua1 strains (Table 1) were similar to those obtained in other actinorhizal plants or legumes transformed with A. rhizogenes (Boisson-Dernier et al. 2001; Diouf et al. 1995; Quandt et al. 1993; Sinharoy et al. 2009; Stiller et al. 1997; Van de Velde et al. 2003). However, genetic transformation resulted in alterations of the root system architecture. This phenotype is due to the presence of the so-called root oncogenic loci ( $r o l)$ genes and the $a u x$ genes involved in auxin biosynthesis in the T-DNA Ri plasmid (Veena and Taylor 2007). Increased auxin levels stimulate lateral root formation and emergence and result in a shallow, bushy root system. This phenotype was more severe with A4RS, suggesting that increased levels of auxin are synthesized in roots generated with this strain. Such a difference in the hairy root phenotype induced by different $A$. rhizogenes strains has been reported in both legumes (Bonaldi et al. 2010; Quandt et al. 1993) and non-legumes (Alpizar et al. 2006; Phelep et al. 1991). Increasing evidence points to a crucial role of auxin in actinorhizal nodulation (Hammad et al. 2003; Péret et al. 2007; PerrineWalker et al. 2010); consequently, we selected the less-disturbing method with the ARqua1 strain.

Given that an imbalance in phytohormones in hairy roots might interfere with nodule development and its regulation
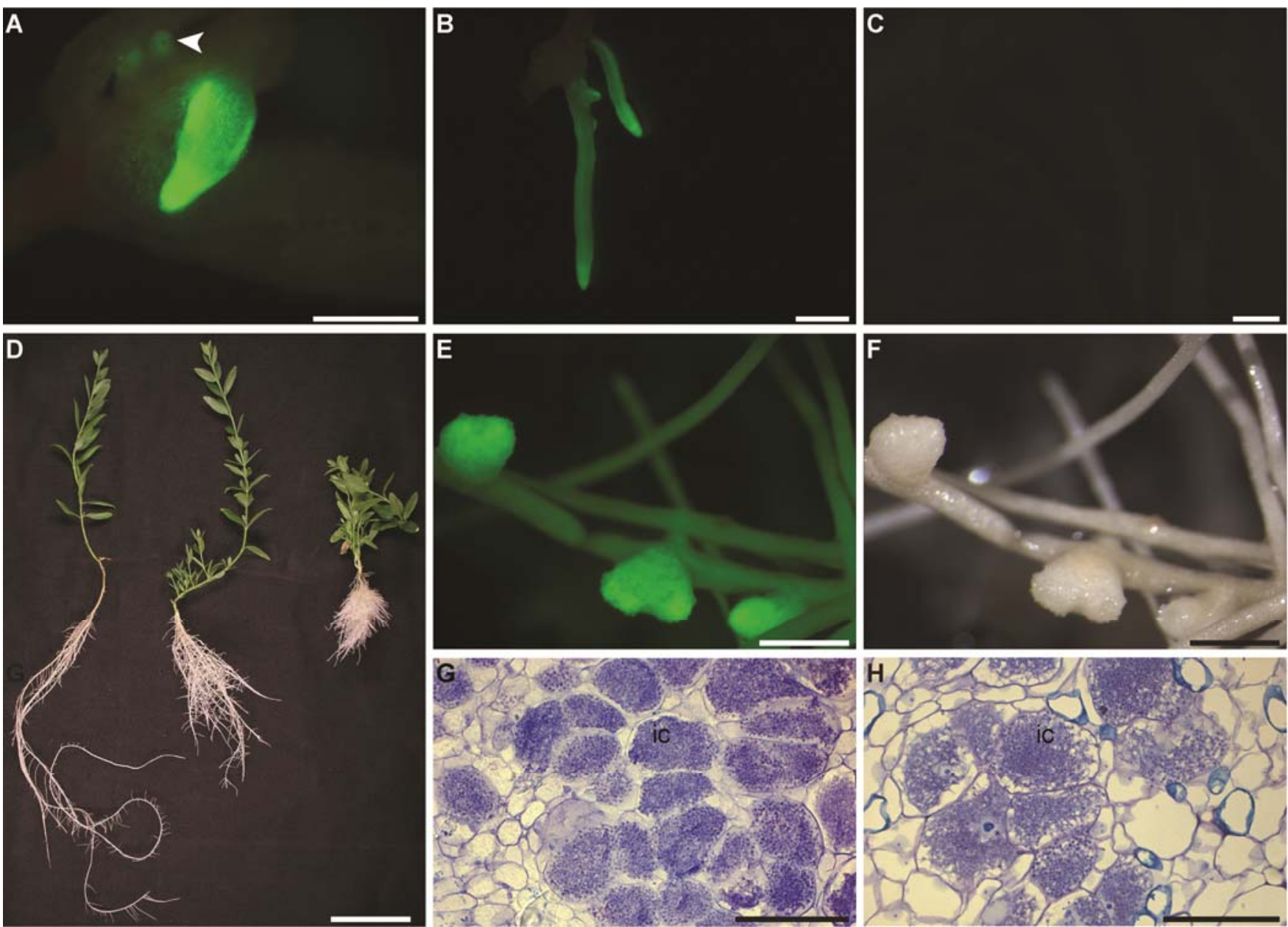

Fig. 1. Phenotype of composite Discaria trinervis plants inoculated with Agrobacterium rhizogenes carrying a $35 \mathrm{~S}:: G F P$ construct. A, Seedling 3 weeks after inoculation (wai) showing small fluorescent calli (arrow) and a fluorescent root. B, Composite plant 4 wai. Co-transformed roots can be easily identified. C, Nontransgenic controls observed under the same conditions as B. D, Representative individuals of nontransgenic control plants (left) and composite plants obtained with the two A. rhizogenes strains: ARqua1 (center) and A4RS (right). E, Nodules induced by Frankia BCU110501 in transformed roots of composite plants, image taken under fluorescent condition. F, Image of the same nodules as E taken under bright light. $\mathbf{G}$ and $\mathbf{H}$, Semithin sections of nodule lobes stained with toluidine blue observed by bright-field microscopy; detail of large cells infected with Frankia (Ic) and harboring numerous vesicles characteristic of the fixation zone. H, Plant transformed with ARqua1. G, Nontransgenic control. A, Bar = $1 \mathrm{~mm}$. B, C, E, and $\mathbf{F}$, Bar $=2 \mathrm{~mm}$. D, Bar = 5 cm. $\mathbf{G}$ and $\mathbf{H}, \mathrm{Bar}=50 \mu \mathrm{m}$. 
(Mulder et al. 2005), we tested whether there was an effect on the nodulation of composite plants compared with nontransgenic controls. According to our results, composite and wild-type plants behave in a similar way in terms of nodule development, nodule anatomy, nitrogen fixation, and strain specificity. The feedback regulation of nodule formation and nitrogen fixation by nitrogen (Wall 2000) was also unaffected (Table 2). Similar experiments performed with $A$. rhizogenes and $C$. glauca revealed no major differences between transgenic and control nodules in shape, anatomy, and nitrogen fixation but, in contrast to D. trinervis, only $40 \%$ of co-transformed root systems were able to develop nodules (Diouf et al. 1995). This difference between the two actinorhizal plants may be due to the infection mechanism because, in Casuarina spp., Frankia bacteria enter through deformed root hairs (Callaham et al. 1979). A. rhizogenes-mediated transformation has a strong effect on root hair development (Veena and Taylor 2007), possibly interfering with root hair penetration. In contrast, $D$. trinervis roots are infected intercellularly without the involvement of root hairs (Valverde and Wall 1999a) and, therefore, may not be affected by the hairy root phenotype.

Among the many possibilities offered by genetic transformation is the analysis of gene expression using reporter genes. Here, we have shown that the expression of two reporter genes, GUS and GFP, can be easily monitored in transgenic $D$. trinervis roots: no endogenous GUS activity is present and tissues are relatively transparent and poorly lignified, resulting in low levels of autofluorescence, a strong GFP signal, and relative permeability to the 5-bromo-4-chloro-3-indolyl b-D-glucuronide (X-gluc) substrate, even in nodules.

The activation pattern of the ProMtEnod11::GUS in relation to actinorhizal symbiosis was recently investigated in two actinorhizal trees infected via the intracellular pathway, $C$. glauca and Allocasuarina verticillata (Svistoonoff et al. 2010b). The ProMtEnod11 activation pattern detected in the infection zone of nodules of $D$. trinervis suggests conservation of the corresponding regulators among all plants able to enter RNS regardless of the infection mechanism. In C. glauca, activation of
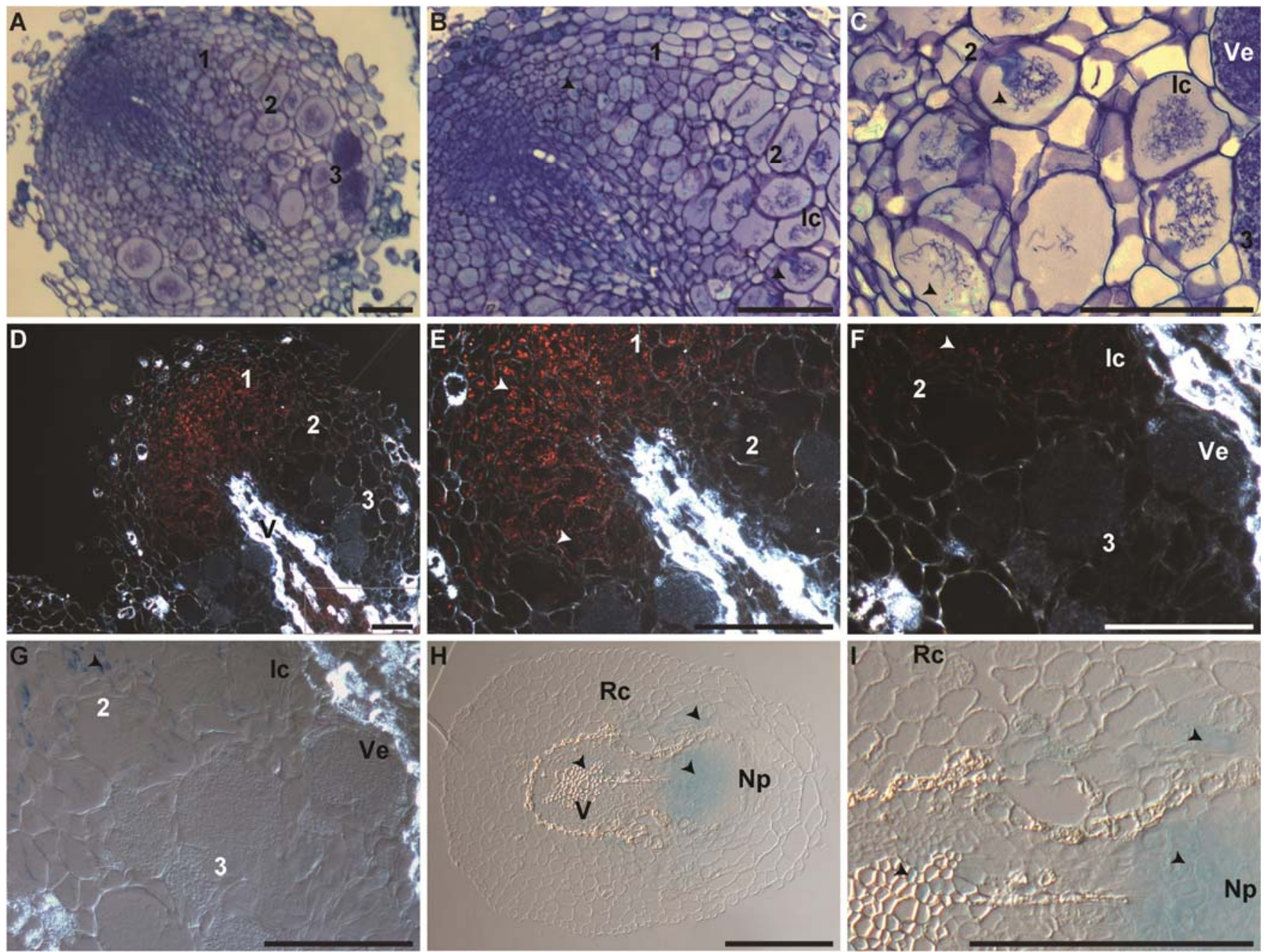

Fig. 2. Histochemical localization of $\beta$-glucuronidase (GUS) activity in Discaria trinervis roots expressing the ProMtEnod11::GUS construct. A to C, Sections stained with toluidine blue to show the pattern of colonization by Frankia bacteria. A, Longitudinal section of a mature nodule lobe showing the three zones characteristic of actinorhizal nodules: the meristematic zone; the infection zone, characterized by the presence of cells infected by Frankia bacteria lacking vesicles; and the fixation zone, where cells infected by Frankia bacteria are full of vesicles. B and C, Details of A. Blue GUS crystals are visible in the meristematic and infection zones. D to G, Adjacent section without toluidine blue showing the localization of GUS activity. Red GUS crystals are present in the meristematic zone, infection zone, and vascular bundle. No GUS staining is detectable in infected cells of the fixation zone. E-G, Details of D. H, Transversal section of a root 1 week after inoculation with Frankia bacteria showing a young nodule primordium. Strong GUS activity is present in some cells of the root vascular bundle, in the meristematic zone of the young nodule primordium, and in cortical cells adjacent to the primordium. I, Detail of H. Arrowheads point to cells showing strong GUS activity. 1, Meristematic zone; 2, infection zone; 3, fixation zone; Ic, infected cells containing Frankia filaments but no vesicles; Ve, vesicles; V, vascular bundle; Np, nodule primordium; Rc, root cortex. A, B, and C, Bright-field microscopy. D, E, and F, Darkfield microscopy. G, H, and I, Differential interference contrast microscopy. Bar $=50 \mu \mathrm{m}$. 
ProMtEnod11 was also detected prior to nodule formation in prenodules and in infected root hairs, and similar results were obtained with two other promoters, ProCg 12 and ProCgAuxl (Péret et al. 2007; Svistoonoff et al. 2003, 2004). We are currently analyzing the activation pattern of these three promoters in D. trinervis at very early stages, when only intercellular infection is present.

These findings open new avenues to study the genetic mechanisms of intercellular root invasion and single-cell infection, allowing detailed characterization of genes involved in $D$. trinervis nodulation and a better understanding of the most ancestral infection pathways leading to RNS. In addition, because $D$. trinervis belongs to the Rosales order, evolutionary comparisons can be made with plants belonging to the same clade but unable to nodulate (most genera of Rosaceae), or with Parasponia spp., the only non-legume able to enter RNS with rhizobia (Op Den Camp et al. 2011). In addition, the transformed roots in $D$. trinervis with appropriate reporter genes would be a powerful tool to explore signaling mechanisms in symbioses with this ancestral infection mode.

\section{MATERIALS AND METHODS}

\section{Plant material and growth conditions.}

Seed from $D$. trinervis were collected in the Pampa de Huenuleo (Bariloche, Argentina). Plants were cultivated in a hydroponics system in a growth chamber or in a greenhouse with photoperiod of at least $18 \mathrm{~h}$ at $150 \mu \mathrm{E} \mathrm{m} \mathrm{m}^{-2} \mathrm{~s}^{-1}$ as previously described (Svistoonoff et al. 2010b).

\section{Binary vectors.}

The binary vector pHKN29 containing a GFP reporter gene fused to the $35 \mathrm{~S}$ promoter (Kumagai and Kouchi 2003) was used to set up the transformation protocols. The ARqua1 strain containing the ProMtEnod11::GUS fusion (Journet et al. 2001) was kindly provided by F. de Carvalho-Niebel (LIPM, Toulouse, France).

\section{Bacterial strains and growth conditions.}

The A. rhizogenes A4RS (Petit et al. 1983) and ARqua1 (Boisson-Dernier et al. 2001) strains were grown at $28^{\circ} \mathrm{C}$ in solidified Ag medium (Franche et al. 1997) with the appropriate antibiotics (Franche et al. 1997), and 4-day-old colonies were used to inoculate $D$. trinervis. The Frankia strains BCU110501 (Chaia 1998), CcI3 (Zhang et al. 1984), and ACN14 (Normand and Lalonde 1982) were cultivated at $26^{\circ} \mathrm{C}$ in a modified BAP medium as previously described (Benoist et al. 1992) and the inoculum was prepared from a 4-day-old culture in exponential growth.

\section{Genetic transformation by A. rhizogenes.}

In vitro. Seed were surface sterilized as previously described (Valverde and Wall 1999b). Seed were immersed in 96\% sulfuric acid for $2 \mathrm{~min}$ and rinsed in running water for $10 \mathrm{~min}$. The seed were then immersed in $\mathrm{NaClO} 5.5 \% \mathrm{wt} / \mathrm{vol}$, commercial bleach, for $5 \mathrm{~min}$ and blotted dry with filter paper, before being left to germinate in petri dishes containing Hoagland \& Arnon medium (Hoagland and Arnon 1950). Two weeks after germination, when plants were approximately 1 to $2 \mathrm{~cm}$ in size, they were transferred in magenta boxes containing a modified Murashige and Skoog medium (MSC) and transformed by $A$. rhizogenes as previously described for $C$. glauca (Diouf et al. 1995). Using a 1.2-by-40-mm needle, A. rhizogenes was inoculated with bacterial culture by stabbing the hypocotyl two to three times. Treated seedlings were transferred to petri dishes without antibiotics for a week and then transplanted in new dishes containing MSC medium with ticarcillin at $250 \mathrm{mg}$ liter ${ }^{-1}$. Co-transformed roots were screened by observing GFP fluorescence under a MZFLIII stereomicroscope (Leica, Wetzlar, Germany) with a GFP2 filter (Leica). Images were acquired using an MP5 camera (Qimaging, Surrey, BC, Canada). Once the roots were 2 to $3 \mathrm{~cm}$ in length, seedlings were transferred to pots containing BD medium (Svistoonoff et al. 2010b) and grown in a culture chamber in mini-greenhouses. Plants were regularly checked under the stereomicroscope and any nontransformed roots were removed.

To analyze the effect of acetosyringone, 3-day-old seedlings were cut at the radicle tip and then scraped onto the surface of an agar plate covered with an A. rhizogenes ARqual culture carrying the pHKN29 vector. The seedlings were then placed in square petri dishes with Hoagland \& Arnon medium, and $100 \mu \mathrm{l}$ of an acetosyringone solution was added at different concentrations $(0,10,25,50$, and $100 \mu \mathrm{M})$ on the surface of the seedlings at the inoculation point. After 1 week, plants were transferred to a new square petri dish with Hoagland \& Arnon medium containing amoxicillin at $300 \mathrm{mg} \mathrm{liter}^{-1}$. The number of plants with co-transformed roots was recorded every week.

Ex vitro. Transformation was performed by adapting the ex vitro method described by Collier and associates (2005). As starting material, we used plants grown in pots in greenhouse conditions. Fragments (4 to $5 \mathrm{~cm}$ ) were excised from young branches with very limited lignification. The cuttings were kept in tap water in a petri dish until inoculation with $A$. rhizogenes ARqual (pHKN29 35S:GFP) without any previous disinfection of the plant material. A fresh culture of $A$. rhizogenes was inoculated approximately $1 \mathrm{~cm}$ from the base of the segment using a needle as described by Diouf and associates (1995). Inoculated segments were transferred into a stone wool cube (Grodan Plugs, Grodan BV, Roermond, The Netherlands). Plants were either continuously watered with demineralized water or subjected to water stress for $48 \mathrm{~h}$ and subsequently watered continuously with demineralized water according to Collier and associates (2005). Plants were then cultivated in a growth chamber under normal conditions $\left(25^{\circ} \mathrm{C}, 45 \%\right.$ humidity on average with a 16 -h photoperiod, 150 $\mu \mathrm{E} \mathrm{m}^{-2}$ ) and watered with demineralized water for 4 to 6 weeks. Segments that produced transformed roots were screened by observing GFP fluorescence as described above. Nonfluorescent roots were removed during the screening process. Shoots showing strongly fluorescent GFP roots were transferred to a hydroponics system. The co-transformation efficiency was calculated by dividing the number of plants with at least one transgenic root by the total number of plants.

\section{Nodulation experiments.}

Plants with a root system of approximately $5 \mathrm{~cm}$ in length were placed in pots containing a BD solution (Svistoonoff et al. 2010b), transferred to a nitrogen-free BD nutrient solution for 1 week, and inoculated with Frankia bacteria as previously described (Franche et al. 1997). Inoculated plants were maintained in the hydroponic system with nitrogen-free BD media for 12 months.

To analyze the specificity of Frankia-host recognition, composite plants grown in pots with BD solution for 5 months were transferred to pouches (Mega International, Minneapolis, MN, U.S.A.), one plant per pouch, watered with nitrogen-free BD solution, and inoculated 1 week later by depositing $1 \mathrm{ml}$ of a suspension of Frankia cells from a 4-week-old culture of strains BCU110501, ACN14, or CCI3 as described by Valverde and Wall (1999a). To look for early nodule induction or plant response, a second experiment was performed: plants were locally inoculated by covering part of their roots with a piece of soft water agar $(0.75 \%)$, which was prepared by mixing equal 
parts of a suspension of Frankia cells with a melted water-agar $1.5 \%$ solution. The roots under the agar were observed under the stereomicroscope until nodule primordia appeared.

\section{Nitrogen fixation activity in composite transformed and nodulated $D$. trinervis plants.}

Nitrogenase activity in living plants was estimated as previously described (Ferrari and Wall 2007) by the ARA (Hardy et al. 1973). We used an Agilent model 6890 plus gas chromatograph with an Omnilab HayeSep T column (1 m in length, 1/8 in. in diameter, $80 / 100$ mesh), operated at $90^{\circ} \mathrm{C}$ (isothermic), with $\mathrm{N}_{2}$ (AGA, Buenos Aires) as carrier gas at $30 \mathrm{ml} / \mathrm{min}$, and an FID detector.

\section{Histochemical GUS assays and microscopy.}

GUS activity was detected in a $50-\mathrm{mM}$ phosphate buffer at pH 8 containing $1 \mathrm{mM} \mathrm{X-gluc,} 1 \mathrm{mM} \mathrm{Na}_{2}$ EDTA, 0.5\% triton (vol/vol), $2 \mathrm{mM} \mathrm{K} \mathrm{K}_{3} \mathrm{Fe}(\mathrm{CN})_{6}$, and $2 \mathrm{mM} \mathrm{K}_{4} \mathrm{Fe}(\mathrm{CN})_{6}$. Explants were incubated at $36^{\circ} \mathrm{C}$ for $12 \mathrm{~h}$ and fixed for $12 \mathrm{~h}$ in $50 \mathrm{mM}$ phosphate buffer, $\mathrm{pH} 7$, containing $0.25 \%$ paraformaldehyde and $4 \%$ glutaraldehyde, and $50-$ or $5-\mu \mathrm{m}$ sections were then cut as previously described (Svistoonoff et al. 2010b). No sectioning was needed prior to GUS staining or resin embedding. Semithin sections were stained with $0.01 \%$ toluidine blue and mounted in Clearium Mountant (Carl Zeiss AG, Oberkochen, Germany). Samples were viewed under a DMRB (Leica) and an AX10 (Zeiss, Weesp, The Netherlands) microscope using bright-field, dark-field, and differential interference contrast microscopy, and images were acquired using an MP5 (Qimaging, Surrey, Canada) digital camera.

\section{ACKNOWLEDGMENTS}

This study was funded by the University of Quilmes (UNQ), the Argentinean National Research Council (CONICET), the Institut de Recherche pour le Développement (IRD), and grants from UNQ (0395/07), CONICET (PIP 2271), IRD Department of Capacity-Building for Southern Scientific Communities (IRD-DPF), Agence Nationale de la Recherche (ANR-08JCJC-0070-01 and ANR-2010 BLAN-1708-01), and ECOS-SUD (A07B02). We thank E. Chaia (U. del Comahue, Bariloche, Argentina) for kindly providing $D$. trinervis seed; F. de Carvalho-Niebel (LIPM, Toulouse, France) for providing the ARqual strain containing the ProMtEnod11::GUS construct; and D. Moukouanga, V. Vaissayre, U. Charbonneau, and J. Bonneau for help with histological work and genetic transformation of $D$. trinervis.

\section{LITERATURE CITED}

Alpizar, E., Dechamp, E., Espeout, S., Royer, M., Lecouls, A. C., Nicole, M., Bertrand, B., Lashermes, P., and Etienne, H. 2006. Efficient production of Agrobacterium rhizogenes-transformed roots and composite plants for studying gene expression in coffee roots. Plant Cell Rep. 25:959-967.

Beach, K. H., and Gresshoff, P. M. 1988. Characterization and culture of Agrobacterium rhizogenes transformed roots of forage legumes. Plant Sci. 57:73-81.

Benoist, P., Müller, A., Diem, H. G., and Schwencke, J. 1992. Highmolecular-mass multicatalytic proteinase complexes produced by the nitrogen-fixing actinomycete Frankia strain BR. J. Bacteriol. 174:14951504

Benson, D. R., and Dawson, J. O. 2007. Recent advances in the biogeography and genecology of symbiotic Frankia and its host plants. Physiol. Plant. 130:318-330.

Boisson-Dernier, A., Chabaud, M., Garcia, F., Bécard, G., Rosenberg, C., and Barker, D. G. 2001. Agrobacterium rhizogenes-transformed roots of Medicago truncatula for the study of nitrogen-fixing and endomycorrhizal symbiotic associations. Mol. Plant-Microbe Interact. 14:695-700.

Boisson-Dernier, A., Andriankaja, A., Chabaud, M., Niebel, A., Journet, E. P., Barker, D. G., and de Carvalho-Niebel, F. 2005. MtENOD11 gene activation during rhizobial infection and mycorrhizal arbuscule development requires a common AT-rich-containing regulatory sequence. Mol. Plant-Microbe Interact. 18:1269-1276.
Bonaldi, K., Gherbi, H., Franche, C., Bastien, G., Fardoux, J., Barker, D., Giraud, E., and Cartieaux, F. 2010. The Nod factor-independent symbiotic signaling pathway: Development of Agrobacterium rhizogenes-mediated transformation for the legume Aeschynomene indica. Mol Plant Microbe Interact. 23:1537-1544.

Callaham, D., Newcomb, W., Torrey, J. G., and Peterson, R. L. 1979. Root hair infection in actinomycete-induced root nodule initiation in Casuarina, Myrica, and Comptonia. Bot. Gaz. 140:1-9.

Capoen, W., Goormachtig, S., De Rycke, R., Schroeyers, K., and Holsters, M. 2005. SrSymRK, a plant receptor essential for symbiosome formation. Proc. Natl. Acad. Sci. U.S.A. 102:10369-10374.

Capoen, W., Den Herder, J., Sun, J., Verplancke, C., De Keyser, A., De Rycke, R., Goormachtig, S., Oldroyd, G., and Holsters, M. 2009. Calcium spiking patterns and the role of the calcium/calmodulin-dependent kinase CCAMK in lateral root base nodulation of Sesbania rostrata. Plant Cell 21:1526-1540.

Chaia, E. 1998. Isolation of an effective strain of Frankia from nodules of Discaria trinervis (Rhamnaceae). Plant Soil 205:99-102.

Collier, R., Fuchs, B., Walter, N., Kevin Lutke, W., and Taylor, C. G. 2005. Ex vitro composite plants: An inexpensive, rapid method for root biology. Plant J. 43:449-457.

Díaz, C., Gronlund, M., Schlaman, H., and Spaink, H. 2005. Induction of hairy roots for symbiotic gene expression studies. Lotus japonicus Handbook. Section 6:261-277. doi: 10.1007/1-4020-3735-X_26.

Díaz, C. L., Melchers, L. S., Hooykaas, P. J., Lugtenberg, B. J., and Kijne, J. W. 1989. Root lectin as a determinant of host-plant specificity in the Rhizobium-legume symbiosis. Nature 38:579-581.

Diouf, D., Gherbi, H., Prin, Y., Franche, C., Duhoux, E., and Bogusz, D. 1995. Hairy root nodulation of Casuarina glauca: A system for the study of symbiotic gene expression in an actinorhizal tree. Mol. PlantMicrobe Interact. 8:532-537.

Ferrari, A. E., and Wall, L. G. 2007. Nodulation and growth of black locust (Robinia pseudoacacia) on a desurfaced soil inoculated with a local Rhizobium isolate. Biol. Fertil. Soils 43:471-477.

Franche, C., Diouf, D., Le, Q. V., Bogusz, D., N'diaye, A., Gherbi, H., Gobé, C., and Duhoux, E. 1997. Genetic transformation of the actinorhizal tree Allocasuarina verticillata by Agrobacterium tumefaciens. Plant J. 11:897-904.

Gabbarini, L. A., and Wall, L. G. 2008. Analysis of nodulation kinetics in Frankia-Discaria trinervis symbiosis reveals different factors involved in the nodulation process. Physiol. Plant. 133:776-785.

Gage, D. J. 2004. Infection and invasion of roots by symbiotic, nitrogenfixing rhizobia during nodulation of temperate legumes. Microbiol. Mol. Biol. Rev. 68:280-300.

Gherbi, H., Markmann, K., Svistoonoff, S., Estevan, J., Autran, D., Giczey, G., Auguy, F., Péret, B., Laplaze, L., Franche, C., Parniske, M., and Bogusz, D. 2008a. SymRK defines a common genetic basis for plant root endosymbioses with arbuscular mycorrhiza fungi, rhizobia, and Frankia bacteria. Proc. Natl. Acad. Sci. U.S.A. 105:4928-4932.

Hammad, Y, Nalin, R., Marechal, J., Fiasson, K., Pepin, R., Berry, A. M., Normand, P., and Domenach, A. M. 2003. A possible role for phenyl acetic acid (PAA) on Alnus glutinosa nodulation by Frankia. Plant Soil 254:193-205

Hardy, R. W. F., Burns, R. C., and Holsten, R. D. 1973. Applications of the acetylene-ethylene assay for measurement of nitrogen fixation. Soil Biol. Biochem. 5:47-81.

Hoagland, D. R., and Arnon, D. I. 1950. The water-culture method for growing plants without soil. Calif. Agric. Exp. Stn. Circ. 347. University of California, Berkeley.

Journet, E. P., El-Gachtouli, N., Vernoud, V., de Billy, F., Pichon, M., Dedieu, A., Arnould, C., Morandi, D., and Barker, D. G., and GianinazziPearson, V. 2001. Medicago truncatula ENOD11: A novel RPRP-encoding early nodulin gene expressed during mycorrhization in arbusculecontaining cells. Mol. Plant-Microbe Interact. 14:737-748.

Kouchi, H., Imaizumi-Anraku, H., Hayashi, M., Hakoyama, T., Nakagawa, T., Umehara, Y., Suganuma, N., and Kawaguchi, M. 2010. How many peas in a pod? Legume genes responsible for mutualistic symbioses underground. Plant Cell Physiol. 51:1381-1397.

Kumagai, H., and Kouchi, H. 2003. Gene silencing by expression of hairpin RNA in Lotus japonicus roots and root nodules. Mol. Plant-Microbe Interact. 16:663-668.

Lerouge, P., Roche, P., Faucher, C., Maillet, F., Truchet, G., Prome, J. C. and Denarié, J. 1990. Symbiotic host-specificity of Rhizobium meliloti is determined by a sulphated and acylated glucosamine oligosaccharide signal. Nature 344:781-784.

Madsen, L. H., Tirichine, L., Jurkiewicz, A., Sullivan, J. T., Heckmann, A. B., Bek, A. S., Ronson, C. W., James, E. K., and Stougaard, J. 2010. The molecular network governing nodule organogenesis and infection in the model legume Lotus japonicus. Nat. Commun. 1:1-12.

Maillet, F., Poinsot, V., André, O., Puech-Pagès, V., Haouy, A., Gueunier, M., 
Cromer, L., Giraudet, D., Formey, D., Niebel, A., Martinez, E. A. Driguez, H., Bécard, G., and Dénarié, J. 2011. Fungal lipochitooligosaccharide symbiotic signals in arbuscular mycorrhiza. Nature 469:58-63.

Markmann, K., Giczey, G., and Parniske, M. 2008. Functional adaptation of a plant receptor-kinase paved the way for the evolution of intracellular root symbioses with bacteria. Plos Biol. 6:e68. Published online.

Mulder, L., Hogg, B., Bersoult, A., and Cullimore, J. V. 2005. Integration of signalling pathways in the establishment of the legume-rhizobia symbiosis. Physiol. Plant. 123:207-218.

Normand, P., and Lalonde, M. 1982. Evaluation of Frankia strains isolated from provenances of two Alnus species. Can. J. Microbiol. 28:1133-1142.

Normand, P., Lapierre, P., Tisa, L. S., Gogarten, J. P., Alloisio, N., Bagnarol, E., Bassi, C. A., Berry, A. M., Bickhart, D. M., Choisne, N., Couloux, A. Cournoyer, B., Cruveiller, S., Daubin, V., Demange, N., Francino, M. P., Goltsman, E., Huang, Y., Kopp, O. R., Labarre, L., Lapidus, A., Lavire, C., Marechal, J., Martinez, M., Mastronunzio, J. E., Mullin, B. C., Niemann, J., Pujic, P., Rawnsley, T., Rouy, Z., Schenowitz, C., Sellstedt, A., Tavares, F., Tomkins, J. P., Vallenet, D., Valverde, C., Wall, L. G., Wang, Y., Medigue, C., and Benson, D. R. 2007. Genome characteristics of facultatively symbiotic Frankia sp. strains reflect host range and host plant biogeography. Genome Res. 17:7-15.

Op den Camp, R., Streng, A., De Mita, S., Cao, Q., Polone, E., Liu, W., Ammiraju, J. S. S., Kudrna, D., Wing, R., Untergasser, A., Bisseling, T., Geurts, R. 2011. LysM-type mycorrhizal receptor recruited for Rhizobium symbiosis in nonlegume Parasponia. Science 331:909-912.

Péret, B., Swarup, R., Jansen, L., Devos, G., Auguy, F., Collin, M., Santi, C., Hocher, V., Franche, C., Bogusz, D., Bennett, M., and Laplaze, L.2007. Auxin influx activity is associated with Frankia infection during actinorhizal nodule formation in Casuarina glauca. Plant Physiol. 144:1852-1862.

Perrine-Walker, F., Doumas, P., Lucas, M., Vaissayre, V., Beauchemin, N. J., Band, L. R., Chopard, J., Crabos, A., Conejero, G., Péret, B., King, J. R., Verdeil, J. L., Hocher, V., Franche, C., Bennett, M. J., Tisa, L. S., and Laplaze, L. 2010. Auxin carriers localization drives auxin accumulation in plant cells infected by Frankia in Casuarina glauca actinorhizal nodules. Plant Physiol. 154:1372-1380.

Petit, A., David, C., Dahl, G. A., Ellis, J. G., Guyon, P., Casse-Delbart, F., and Tempe, J. 1983. Further extension of the opine concept: Plasmids in Agrobacterium rhizogenes cooperate for opine degradation. Mol. Gen. Genet. 190:204-214.

Petit, A., Stougaard, J., Kühle, A., Marcker, K. A., and Tempé, J. 1987. Transformation and regeneration of the legume Lotus corniculatus: A system for molecular studies of symbiotic nitrogen fixation. Mol. Gen. Genet. 207:245-250.

Phelep, M., Petit, A., Martin, L., Duhoux, E., and Tempé, J. 1991. Transformation and regeneration of a nitrogen-fixing tree, Allocasuarina Verticillata Lam. Nat. Biotechnol. 9:461-466.

Quandt, H. J., Pühler, A., and Broer, I. 1993. Transgenic root nodules of Vicia hirsuta: A fast and efficient system for the study of gene expression in indeterminate-type nodules. Mol. Plant-Microbe Interact. 6:699-706.

Sinharoy, S., Saha, S., Chaudhury, S. R., and DasGupta, M. 2009. Transformed hairy roots of Arachis hypogea: A tool for studying root nodule symbiosis in a non-infection thread legume of the Aeschynomeneae tribe. Mol. Plant-Microbe Interact. 22:132-142.

Soltis, D. E., Soltis, P. S., Morgan, D. R., Swensen, S. M., Mullin, B. C., Dowd, J. M., and Martin, P. G. 1995. Chloroplast gene sequence data suggest a single origin of the predisposition for symbiotic nitrogen fixation in angiosperms. Proc. Natl. Acad. Sci. U.S.A. 92:2647-2651.

Sprent, J. I. 2007. Evolving ideas of legume evolution and diversity: A taxonomic perspective on the occurrence of nodulation. New Phytol. 174:11-25.
Stiller, J., Martirani, L., Tuppale, S., Chian, R. J., Chiurazzi, M., and Gresshoff, P. M. 1997. High frequency transformation and regeneration of transgenic plants in the model legume Lotus japonicus. J. Exp. Bot. 48:1357.

Stougaard, J., Petersen, T. E., and Marcker, K. A. 1987. Expression of a complete soybean leghemoglobin gene in root nodules of transgenic Lotus corniculatus. Proc. Natl. Acad. Sci. U.S.A. 84:5754-5757.

Streeter, J., and Wong, P. P. 1988. Inhibition of legume nodule formation and $\mathrm{N}_{2}$ fixation by nitrate. Crit. Rev. Plant. Sci. 7:1-23.

Svistoonoff, S., Laplaze, L., Auguy, F., Runions, J., Duponnois, R., Haseloff, J., Franche, C., and Bogusz, D. 2003. cg12 expression is specifically linked to infection of root hairs and cortical cells during Casuarina glauca and Allocasuarina verticillata actinorhizal nodule development. Mol. Plant-Microbe Interact. 16:600-607.

Svistoonoff, S., Laplaze, L., Liang, J., Ribeiro, A., Gouveia, M. C., Auguy, F., Fevereiro, P., Franche, C., and Bogusz, D. 2004. Infection-related activation of the $\operatorname{cg} 12$ promoter is conserved between actinorhizal and legume-rhizobia root nodule symbiosis. Plant Physiol. 136:3191-3197.

Svistoonoff, S., Gherbi, H., Nambiar-Veetil, M., Zhong, C., Michalak, Z., Laplaze, L., Vaissayre, V., Auguy, F., Hocher, V., Doumas, P., Bonneau, J., Bogusz, D., and Franche, C. 2010a. Contribution of transgenic Casuarinaceae to our knowledge of the actinorhizal symbioses. Symbiosis 50:3-11.

Svistoonoff, S., Sy, M., Diagne, N., Barker, D. G., Bogusz, D., and Franche, C. 2010b. Infection-specific activation of the Medicago truncatula Enod11 early nodulin gene promoter during actinorhizal root nodulation. Mol. Plant-Microbe Interact. 23:740-747.

Valverde, C., and Wall, L. G. 1999a. Regulation of nodulation in Discaria trinervis (Rhamnaceae)-Frankia symbiosis. Botany 77:1302-1310.

Valverde, C., and Wall, L. G. 1999b. Time course of nodule development in the Discaria trinervis (Rhamnaceae)-Frankia symbiosis. New Phytol. 141:345-354.

Valverde, C., and Wall, L. G. 2002. Nodule distribution on the roots of actinorhizal Discaria trinervis (Rhamnaceae) growing in pots. Environ. Exp. Bot. 47:95-100.

Valverde, C., Wall, L. G., and Huss-Danell, K. 2000. Regulation of nodulation and nodule mass relative to nitrogenase activity and nitrogen demand in seedlings of Discaria trinervis (Rhamnaceae). Symbiosis 28:49-62

Van de Velde, W., Mergeay, J., Holsters, M., and Goormachtig, S. 2003. Agrobacterium rhizogenes-mediated transformation of Sesbania rostrata. Plant Sci. 165:1281-1288.

Veena, V., and Taylor, C. G. 2007. Agrobacterium rhizogenes: Recent developments and promising applications. In Vitro Cell Dev. Biol. 43:383403.

Vessey, J. K., Pawlowski, K., and Bergman, B. 2005. Root-based $\mathrm{N}_{2}$-fixing symbioses: Legumes, actinorhizal plants, Parasponia sp. and cycads. Plant Soil 266:205-230.

Wall, L. G. 2000. The actinorhizal symbiosis. J. Plant Growth Regul. 19:167-182.

Wall, L. G., and Berry, A. M. 2008. Early interactions, infection and nodulation in actinorhizal symbiosis. Pages 147-166 in: Nitrogen Fixation: Origins, Applications, and Research Progress, Vol. 6. Nitrogen-Fixing Actinorhizal Symbioses. K. Pawlowski and W. E. Newton, eds. Springer, Dprdrecht, The Netherlands.

Wall, L. G., Valverde, C., and Huss-Danell, K. 2003. Regulation of nodulation in the absence of $\mathrm{N}_{2}$ is different in actinorhizal plants with different infection pathways. J. Exp. Bot. 54:1253-1258.

Zhang, Z., Lopez, M. F., and Torrey, J. G. 1984. A comparison of cultural characteristics and infectivity of Frankia isolates from root nodules of Casuarina species. Plant Soil 78:79-90. 